\title{
De Novo Accumulation of Tetrodotoxin and Its Analogs in Pufferfish and Newt and Dosage-Driven Accumulation of Toxins in Newt: Tissue Distribution and Anatomical Localization
}

\author{
Shigeru Sato *, Rika Kawaura, Kaito Togashi, Nanami Mizusawa, Ko Yasumoto, Kentaro Takada, Masafumi Amano \\ and Shugo Watabe (D) \\ School of Marine Biosciences, Kitasato University, Minami-ku, Sagamihara 252-0373, Kanagawa, Japan; \\ mf18002@st.kitasato-u.ac.jp (R.K.); fm16121@st.kitasato-u.ac.jp (K.T.);nmizusaw@kitasato-u.ac.jp (N.M.); \\ yasumoto@kitasato-u.ac.jp (K.Y.); ktakada@kitasato-u.ac.jp (K.T.); amanoma@kitasato-u.ac.jp (M.A.); \\ swatabe@kitasato-u.ac.jp (S.W.) \\ * Correspondence: shigeru@kitasato-u.ac.jp
}

check for updates

Citation: Sato, S.; Kawaura, R.; Togashi, K.; Mizusawa, N.; Yasumoto, K.; Takada, K.; Amano, M.; Watabe, S. De Novo Accumulation of Tetrodotoxin and Its Analogs in Pufferfish and Newt and Dosage-Driven Accumulation of Toxins in Newt: Tissue Distribution and Anatomical Localization. J. Mar. Sci. Eng. 2021, 9, 1004. https:// doi.org/10.3390/jmse9091004

Academic Editors: Naomasa Oshiro, Ana Gago-Martínez and Aurelia Tubaro

Received: 27 August 2021

Accepted: 9 September 2021

Published: 14 September 2021

Publisher's Note: MDPI stays neutral with regard to jurisdictional claims in published maps and institutional affiliations.

Copyright: (c) 2021 by the authors. Licensee MDPI, Basel, Switzerland. This article is an open access article distributed under the terms and conditions of the Creative Commons Attribution (CC BY) license (https:/ / creativecommons.org/licenses/by/ $4.0 /)$.

\begin{abstract}
The present study was undertaken to determine the amounts of tetrodotoxin (TTX) and its analogs (TTXs) in various tissues of toxin-bearing pufferfish (Canthigaster revulata and Takifugu flavipterus) and newt (Cynops pyrrhogaster) using specific polyclonal antibodies against TTXs, and to compare the obtained results with those mainly determined by high-performance liquid chromatography with fluorescence detection (HPLC-FLD). The anatomical localization of TTXs in these animals was also demonstrated immunohistochemically using the above-mentioned antibody. The ratio of the total amount of TTXs determined by ELISA to that determined by HPLC-FLD changed depending on the tissues examined in pufferfish. Such differences were also observed with the newt in tissueand individual-dependent manners. Furthermore, TTXs, as well as decarbamoylsaxitoxin (dcSTX), an analog of saxitoxin (STX), were traced for their dynamic changes in tissue distribution, when the newt was fed authentic toxins or toxic animal tissues exogenously, demonstrating that a TTX analog, 5,6,11-trideoxyTTX, and dcSTX were not metabolized into TTX or STX. TTXs-immunoreactive (ir) staining was observed in the pancreas region of the hepatopancreas, the oocytes at the perinucleolus stage, the sac-like tissues just outside the serous membrane of the intestine, and the gland-like structure of the skin, but not in the muscles of pufferfish. TTXs-ir staining was also detected in the mature glands in the dermis of the adult and regenerated tail, but not in the liver, intestine, testis and ovary of the adult newt. TTXs-ir staining was detected in the epithelial cells of the intestine, the ovary, the mucous cells, and the dermis of the TTXs-administered newt. These results suggest that TTXs absorbed from the environment are distributed to various organs or tissues in a species-specific manner, regardless of whether or not these are metabolized in the bodies of toxin-bearing animals.
\end{abstract}

Keywords: anatomy; immunohistochemical localization; newt; pufferfish; paralytic shellfish toxins; decarbamoylsaxitoxin; tetrodotoxin; tetrodotoxin analogs

\section{Introduction}

Tetrodotoxin (TTX), one of the most potent natural neurotoxins [1,2], was first detected in pufferfish $[3,4]$. Subsequently, TTX was found in various organisms, including vertebrates and invertebrates [5-8], and even in bacteria [9-11]. Besides TTX, paralytic shellfish toxins (PSTs) such as saxitoxin and its related compounds are also potent natural neurotoxins, distributed not only to shellfish but also fish, and are known to originate from the toxic products of dinoflagellate [12]. It is interesting that some pufferfish have both TTX and PSTs in their body [12-14].

We have recently developed a novel polyclonal antibody against TTX using its haptenic antigen [15]. This newly developed polyclonal antibody with analytical procedures using direct one-step ELISA (TTX-ELISA kit) has been demonstrated to be useful to detect 
TTX and its analogs (TTXs) in toxic organisms $[15,16]$. This assay kit is comparably efficient with our previously developed ELISA kit, which recognizes PSTs [17].

TTX is abundant in internal organs, such as the hepatopancreas (frequently written as liver for pufferfish in many references in place of the correct organ name) and ovaries of most pufferfish. It is also frequently distributed into skin and less often into muscle [8]. Such tissue distribution has been well demonstrated anatomically in pufferfish, such as Tetraodon steindachneri and Takifugu niphobles, by employing monoclonal antibodies raised against TTX [18-20]. This strategy was also successful for the detection of TTX in the secretory glands in the skin of the Japanese newt Cynops pyrrhogaster [21], and the redspotted newt Notophthalmus viridescens [22]. Interestingly, such TTX secretion from the secretory gland well confirms the previous observation by Kodama and his colleagues, who found specific organs secreting TTX in pufferfish [23].

Recently, various analogs of TTX have been identified, and some of them are contained in TTX-bearing animals at appreciable amounts [24,25]. Interestingly, 5,6,11-trideoxy (TDT), one of the analogs of TTX, was dominant in various tissues of Takifugu pardalis pufferfish [25], and it was exclusively found in the liver (hepatopancreas), testis and even muscle of Lagocephlus spadiceus pufferfish [16]. Although the immunohistochemical approach is very powerful in investigating the anatomical localization of TTX, as mentioned above, its monoclonal antibody so far prepared [26-29] has not been investigated for its reactivity with its analogs. On the other hand, our polyclonal antibody very recently raised against TTX was conjugated with keyhole limpet hemocyanin (KLH) via a sophisticated method, where 4,9-anhydroTTX prepared from TTX was reacted with 1,2-ethanedithiol, and was found to react not only with TTX, but also well with its analogs, except for 4,9-anhydroTTX [15]. It is noted that this system was established by referring to our development of a novel polyclonal antibody raised against PSTs based on the unique reactions between C11-O-sulfate toxins, such as gonyautoxins 2 and 3 (GTX2,3), and various thiol compounds, followed by coupling to KLH [17]. Although TDT is predicted to be a precursor of TTX and converted to TTX by endogenous and/or exogenous factors [25], exact pathway(s) have remained unknown. Therefore, our polyclonal antibody, which recognizes various TTX analogs, seems a promising tool to survey the metabolic pathway(s) of TTX and the anatomical localization of possible precursors of TTX.

The main objective of the present study was to analyze TTXs in various tissues of newt using the specific polyclonal antibody against TTXs, and to compare the obtained results with those measured predominantly by well-established high-performance liquid chromatography with fluorescence detection (HPLC-FLD). Liquid chromatography/mass spectrometry (LC-MS) was employed only for the determination of TDT. These values were first measured in toxin-bearing pufferfish to confirm the availability of the antibody. The anatomical localization of TTXs in these animals was also demonstrated via an immunohistochemical procedure using the polyclonal antibody. Furthermore, TTXs as well as PSTs were traced for their dynamic changes in tissue distribution, when these animals were fed toxic animal tissues exogenously.

\section{Materials and Methods}

\subsection{Materials}

One individual globefish puffer Takifugu flavipterus (female, body weight $42.9 \mathrm{~g}$, total length $125 \mathrm{~mm}$ ) and one individual brown-lined puffer Canthigaster revulata (male, body weight $148.8 \mathrm{~g}$, total length $193 \mathrm{~mm}$ ) caught in the Pacific Ocean off the Miura Peninsula, Kanagawa Prefecture, Japan, were kindly supplied in 27 February 2019 by Dr. Seiji Akimoto (Kanagawa Prefectural Fisheries Technology Center, Japan). These specimens were collected before spawning by licensed fishermen and transported to the laboratory at the School of Marine Biosciences, Kitasato University. Alive specimens were placed on ice for the sake of anesthetization and dissected into several tissues, including hepatopancreas, intestine, muscle, skin and gonads. 
Several wild specimens of Japanese fire-bellied newt Cynops pyrrhogaster were collected from rice farm fields in Kan-nami, Shizuoka Prefecture, Japan, on 3 October 2018, prior to hibernation (adults, about $10 \mathrm{~cm}$; juveniles, about $4 \mathrm{~cm}$ ), and on 24 May 2019, during spawning season (adults, about $10 \mathrm{~cm}$ ). Twenty-eight adult specimens were reared by feeding artificial food specially designed for newts (JAN code No. 4971453054017) (Itosui, Tokyo, Japan) in the laboratory before experiments. The eggs of the newt and larva immediately after hatching were also obtained by rearing specimens in the laboratory. All live specimens (adult, juvenile and larva) of newt were placed on ice for anesthesia, and adults were dissected into several tissues, including the hepatopanreas, intestine, skin, tail, and gonads. Only the tail was subjected to the experiments for juveniles ( 9 specimens) and the whole body was used for hatched larva (10 specimens). Jelly layers and yolks were dissected from the eggs spawned by 10 matured specimens, pooled respectively, and subjected to toxin analysis. The whole bodies of 10 hatched larvae were also pooled and subjected to the toxin analysis.

Decarbamoylsaxitoxin (dcSTX) prepared previously from the toxic Yezo giant scallop Mizuhopecten yessoensis [30] was used as the authentic PST for feeding experiments of the newt. The globefish puffer hepatopancreas was also used for feeding experiments of the newt. While adult specimens collected on 24 May 2019 were employed for feeding experiments with dcSTX, juveniles collected on 3 October 2018 were used for those with the globefish puffer hepatopancreas and TDT.

Animal treatment in this study was conducted in compliance with the codes of ethics at Kitasato University, MB1800510 and MB190510.

All the reagents were of analytical grade and purchased from FUJIFILM Wako Pure Chemical Co., Osaka, Japan, unless specified otherwise.

\subsection{Preparation of the Extract and Assay Procedures for TTXs}

TTXs were extracted from 2 and $0.1 \mathrm{~g}$ of sample tissues from pufferfish and newts, respectively, with $0.1 \%(v / v)$ acetic acid by heating in a boiling water bath for $10 \mathrm{~min}$, according to the method for TTX described in the Standard Methods of Analysis in Food Safety, Japan [31].

The total concentrations of TTXs in tissue extracts were determined by ELISA, essentially according to Sato et al. [15]. Briefly, the polyclonal antibody prepared by Sato et al. was diluted 100 times with $0.9 \%(w / v) \mathrm{NaCl}$ in $0.01 \mathrm{M}$ Tris- $\mathrm{HCl}$ buffer ( $\mathrm{pH} 8.2)$, and $100 \mu \mathrm{L}$ portions were added to each well of a 96-well ELISA plate (Maxisorp, Thermo Fisher Scientific, Waltham, MA, USA). After stirring at $4{ }^{\circ} \mathrm{C}$ overnight, the plate was washed with phosphate-buffered saline free of $\mathrm{Ca}^{2+}$ and $\mathrm{Mg}^{2+}(\mathrm{PBS}(-))$, added each with $350 \mu \mathrm{L}$ Block Ace $\left(4 \% w / v\right.$ in water; KAC Co., Ltd., Kyoto, Japan) solution, and left to stand at $4{ }^{\circ} \mathrm{C}$ overnight. The plate was washed with PBS(-) containing 0.05\% $(v / v)$ Tween 20 (PBSTw) twice. Then, the sample extract containing $0.2 \mathrm{~g}$ tissue $/ \mathrm{mL}$ was diluted $10-1000$-fold with $0.1 \mathrm{M}$ sodium phosphate buffer ( $\mathrm{pH} 7.4$ ) and $50 \mu \mathrm{L}$ of solution was added to each well of the ELISA plate coated with the antibody specific to the TTXs. Next, $50 \mu \mathrm{L}$ Biotin-TTX ( $2 \mathrm{nM}$, diluted with the same buffer) was added to each well and the plate was incubated at $37^{\circ} \mathrm{C}$ for $15 \mathrm{~min}$. After the solution was discarded, the wells were washed with PBSTw and added with $50 \mu \mathrm{L}$ horseradish peroxidase (HRP)-streptavidin solution (2000 times dilution with PBS(-); Funakoshi, Tokyo, Japan). The plate was incubated at $37^{\circ} \mathrm{C}$ for $15 \mathrm{~min}$ and the solution was discarded. After washing the wells three times with PBSTw, $100 \mu \mathrm{L}$ of a solution of Sigma-Fast tablets (OPD- $\mathrm{H}_{2} \mathrm{O}_{2}$, Sigma-Aldrich, St. Louis, MO, USA) dissolved in $10 \mathrm{~mL}$ pure water was added to each well. The plate was incubated at $37^{\circ} \mathrm{C}$ for $5 \mathrm{~min}$, and to the wells was added $100 \mu \mathrm{L} \mathrm{HCl}(2 \mathrm{M})$. The plate was subjected to measurement of absorbance at $490 \mathrm{~nm}$ with a plate reader (iMark, Bio-Rad, Herculus, CA, USA). The toxin solution samples were analyzed in triplicate. The limit of detection (LOD) and working range of ELISA were approximately $3 \mathrm{nM}$ and $10-300 \mathrm{nM}$, respectively [15].

TTX, TTX-6-epimer (6-epiTTX), TTX-4-epimer (4-epiTTX) and 4,9-anhydroTTX were analyzed by HPLC-FLD according to Yotsu et al. [32] with minor modifications. Briefly, HPLC- 
FLD was performed as follows: HPLC column, J-Pak Symphonia C18 $(5 \mu \mathrm{m}, 4.6 \times 150 \mathrm{~mm}$; Jasco, Tokyo, Japan); mobile phase, $0.06 \mathrm{M}$ heptafluorobutiric acid (HFBA, 98\%; SigmaAldrich) $/ 0.05 \mathrm{M}$ ammonium acetate buffer ( $\mathrm{pH} 5.0), 0.4 \mathrm{~mL} / \mathrm{min}$; reaction reagent, $4 \mathrm{M}$ sodium hydroxide, $0.4 \mathrm{~mL} / \mathrm{min}$; detector, FP-2020 Plus (Jasco, Ex $365 \mathrm{~nm}$, Em $510 \mathrm{~nm}$, Gain $\times 1000$ ); pump for mobile phase, PU-2080 Plus (Jasco, Tokyo, Japan); pump for reaction reagent, PU-2080 Plus (Jasco, Tokyo, Japan); reaction coil, i.d. $0.5 \mathrm{~mm} \times 200 \mathrm{~cm}$ (stainless, $120^{\circ} \mathrm{C}$ in dry oven); integrator, Chromatocorder 21 (SIC, Tokyo, Japan); injection volume, $10 \mu \mathrm{L}$ (overload injection). The authentic standards for HPLC-FLD consisted of 15.2 $\mu \mathrm{M}$ TTX, 9.5 $\mu \mathrm{M}$ 6-epiTTX, $12.8 \mu \mathrm{M}$ 4-epiTTX and $11.8 \mu \mathrm{M}$ 4,9-anhydroTTX in $0.03 \mathrm{M}$ acetic acid ( $>96 \%$, as acetic acid salt, calculated from freeze-dried weight), which were prepared as described in the following Section 2.3. The LODs of TTX, 6-epiTTX, 4-epiTTX and 4,9-anhydroTTX were approximately $30 \mathrm{nM}$ each, and their good linearity $\left[Y=1.31 \times 10^{3} X+0.00\left(R^{2}=0.9987\right)\right.$ for TTX, $Y=3.07 \times 10^{3} X+0.01\left(R^{2}=0.9908\right)$ for 6-epiTTX, $Y=1.69 \times 10^{3} X+0.00\left(R^{2}=0.9956\right)$ for 4-epiTTX, $Y=1.53 \times 10^{3} X+0.00$ $\left(R^{2}=0.9902\right)$ for 4,9 -anhydroTTX; $X=$ conc. $(\mu \mathrm{M}), Y=$ peak area $\left.(\mathrm{mVsec})\right]$ was in the range of $0.1-100 \mu \mathrm{M}$

TDT was identified according to Sato et al. [15] by LC-MS (Triple TOF ${ }^{\mathrm{TM}} 5600^{+}$; SCIEX, Framingham, MA, USA) as follows: column, Atlantis HILIC (Waters, Milford, MA, USA), $3 \mu \mathrm{m}, 2.1 \times 150 \mathrm{~mm}$; mobile phase A, acetonitrile; mobile phase $\mathrm{B}, 10 \mathrm{mM}$ ammonium formate buffer ( $\mathrm{pH} 4.0$ ); flow rate, $0.2 \mathrm{~mL} / \mathrm{min}$; injection volume, $5 \mu \mathrm{L}$; $\mathrm{CE}$ values, $30 \pm 10 \mathrm{eV}$; gradient, $0 \mathrm{~min}(\mathrm{~B}: 20 \%) \rightarrow>15 \mathrm{~min}(\mathrm{~B}: 60 \%) \rightarrow>16 \min (\mathrm{B}: 60 \%) \rightarrow$ $>16.1 \mathrm{~min}$ (B: $20 \%) \rightarrow>19 \mathrm{~min}$ (B: $20 \%$ ); mode, TOF-MS, operated in a positive ion mode via electrospray ionization.

\subsection{Preparation of Standard TTX and Its Analogs}

TTX and its analogs 4-epiTTX, 4,9-anhydroTTX and TDT were prepared previously from the visceral parts of globefish puffer [15].

\subsection{Analytical Procedures of dcSTX}

dcSTX fed on animals and recovered in various tissues of the newt was quantitated by HPLC-FLD according to Oshima [33].

\subsection{Feeding Experiments}

The globefish puffer hepatopancreas described in Section 2.1 was used for feeding experiments of the newt, employing 5 larvae collected on 3 October 2018, with a supposed age of 5 months. Two specimens were reared individually in plastic tanks for one month with non-toxic artificial food specially designed for newt and then fed toxic samples, whereas three individuals were fed non-toxic food throughout. Each of two specimens was provided with three small pieces of the globefish puffer hepatopancreas (ca. $50 \mathrm{mg}$ in total) once a week and subjected to a determination of toxin components and immunohistochemical procedures after the 10 -fold dosage.

One specimen of juvenile newt collected on 3 October 2018 was also fed three pellets of diet containing $2.0 \mathrm{mM}$ TDT ( $24 \mathrm{mg}$ in total, corresponding to $35 \mathrm{nmol}$ TDT) five days a week and reared for 4 weeks. Authentic TDT isolated from globefish puffer [15] was used in this experiment.

dcSTX prepared previously from the toxic Yezo giant scallop Mizuhopecten yessoensis [30] was also used as the authentic PST for feeding experiments of the newt. Two adult specimens collected on 25 May 2019 were individually provided with three pellets each, five days a week, and reared for 4 weeks. The three pellets contained $24 \mathrm{mg}$ in total, corresponding to $31 \mathrm{nmol}$ dcSTX.

\subsection{Immunohistochemistry}

Each pufferfish specimen was dissected into different organs, whereas newt bodies were divided into 2 or 3 parts (according to body size) from the head to the tail. These 
organs and parts were fixed with freshly prepared Bouin's fluid at $4{ }^{\circ} \mathrm{C}$ for $24 \mathrm{~h}$. Bouin's fluid was prepared by mixing saturated 2,4,6-trinitrophenol (picric acid), neutral buffered formalin, and acetic acid in the ratio of 15:5:1 $(v / v / v)$. Fixed samples were subsequently rinsed in cold $70 \%$ ethanol, dehydrated through a graded series of ethanol concentrations until 100\%, and then embedded in paraplast (Monoject, Sherwood Medical, St. Louis, MO, USA). Sagittal sections were cut at $8 \mu \mathrm{m}$ with a microtome (RM2125 RTS, Leica Biosystems Nussloch GmbH, Nussloch, Germany), and mounted on MAS-GP-coated slides (Matsunami, Osaka, Japan). Sections were stored at $4{ }^{\circ} \mathrm{C}$ until use.

Immunohistochemistry was performed according to the method described by Amano et al. [34] using a Histofine immunostaining kit (SAB-PO (R), Nichirei Biosciences, Tokyo, Japan). The paraplast sections were deparaffinized in clear plus (Falma, Tokyo, Japan) twice for $10 \mathrm{~min}$ each. Next, they were rehydrated through graded ethanol concentrations and twice in distilled water for 5 min each. Endogenous peroxidase activity in the sections was blocked with 3\% $(w / v)$ hydrogen peroxide in PBS containing 0.3\% $(v / v)$ Triton-X (PBSTr) for $30 \mathrm{~min}$ at room temperature. After washing the sections three times with PBSTr for 10 min each, a blocking solution with $10 \%$ normal goat serum was applied to the sections for $15 \mathrm{~min}$ at room temperature. After washing the sections three times with PBSTr for $10 \mathrm{~min}$ each, the sections were incubated with the antibody against TTX at $4{ }^{\circ} \mathrm{C}$ overnight. Anti-TTX antibody was diluted 500-fold with PBSTr containing $0.02 \%(w / v)$ bovine serum albumin (Vector Laboratories Inc, Burlingame, CA, USA). After washing the sections three times with PBSTr for 10 min each, the sections were added with biotin-labeled anti-rabbit IgG and incubated for $15 \mathrm{~min}$ at room temperature. After washing the sections three times with PBSTr for $10 \mathrm{~min}$ each, peroxidase-labeled streptavidin was added to the sections for $15 \mathrm{~min}$ at room temperature. After again washing the sections three times with PBSTr for $10 \mathrm{~min}$ each, peroxidase activity was visualized in $0.1 \mathrm{M}$ phosphate buffer $(\mathrm{pH} 7.4)$ containing $0.05 \%(w / v) 3^{\prime}, 3^{\prime}$-diaminobenzidine tetrahydrochloride (DAB), and $0.01 \%(w / v)$ hydrogen peroxide. Immunoreaction was stopped in distilled water. The sections were counterstained with Mayer's hematoxylin. Finally, the sections were dehydrated through a graded series of ethanol concentrations, cleared in clear plus, and coverslipped in Permount (Fischer, Fair Lawn, NJ, USA).

To test the specificity of the immunoreactions, the control sections were incubated in the anti-TTX antibody that had been pre-absorbed at $4{ }^{\circ} \mathrm{C}$ overnight with excessive amounts of TTXs, which were used as the authentic standards for HPLC-FLD (see Section 2.2) and diluted 5 -fold $(v / v)$ with the antibody solution. The subsequent procedure was identical to that used for the abovementioned section preparation.

Sections were observed with a microscope (BX50, Olympus, Tokyo, Japan) and photographs were taken by digital camera (FX380, Olympus). For the terminology of the skin of the newt, we referred to Tsuruda et al. [21].

\section{Results}

3.1. Tissue Distribution of TTXs Determined with TTX-ELISA Kit and HPLC-FLD in Wild Specimens of Pufferfish and Newt

The amount of TTXs in globefish puffer was much higher than that in brown-lined puffer, irrespective of tissues examined by TTX-ELISA or HPLC-FLD (Tables 1 and 2). It was noted that the amounts of TTXs in brown-lined puffer determined by ELISA were generally higher than those of TTXs determined by HPLC -FLD (Table 2). However, the ratio of the total amount of TTXs determined by ELISA to that determined by HPLC-FLD was changed depending on tissues examined for globefish puffer: the ratio was over 1000 for the skin and 0.50 for the ovary (Table 1). While 6-epiTTX and 4-epiTTX were not highly present in the two puffers, globefish puffer showed relatively high amounts of 4,9-anhyroTTX. 
Table 1. Amount of TTX and its analogs in the globefish puffer Takifugu flavipterus (nmol/g) $(n=1)$.

\begin{tabular}{cccccccc}
\hline \multirow{2}{*}{ Tissue } & ELISA & \multicolumn{5}{c}{ HPLC-FLD } \\
\cline { 2 - 6 } & TTXs & TTX & 6-epiTTX & 4-epiTTX & 4,9-anhydroTTX & Total \\
\hline Hepatopancreas & $39,953.2$ & 239.6 & $<0.1$ & 37.9 & 51.7 & 329.2 \\
Intestine & 599.1 & 367.0 & $<0.1$ & $<0.1$ & 169.3 & 121.4 \\
Muscle & 203.9 & 288.4 & $<0.1$ & $<0.1$ & 53.6 & 536.3 \\
Skin & $14,829.2$ & 10.6 & $<0.1$ & $<0.1$ & 3.0 & 1.1 \\
Ovary & 2176.8 & 4341.8 & $<0.1$ & 31.7 & $<0.1$ & 13.6 & 1090.4 \\
\hline
\end{tabular}

* Enzyme-linked immunosorbent assay (ELISA) determines total amount of tetorodotoxin (TTX) and its analogs (TTXs) including 6-epiTTX, 4-epiTTX, and 5,6,11-trideoxyTTX, but not 4,9-anhydroTTX. ${ }^{* *}$ High-performance liquid chromatography with fluorescence detection. *** The ratio of amount of TTXs determined by ELISA to that determined by HPLC-FLD.

Table 2. Amount of TTX and its analogs in the brown-lined puffer Canthigaster revulata (nmol/g) $(n=1)$.

\begin{tabular}{|c|c|c|c|c|c|c|c|}
\hline \multirow{2}{*}{ Tissue } & \multirow{2}{*}{$\begin{array}{c}\text { ELISA * } \\
\text { TTXs }\end{array}$} & \multicolumn{5}{|c|}{ HPLC-FLD } & \multirow{2}{*}{ Fold ** } \\
\hline & & TTX & 6-epiTTX & 4-epiTTX & 4,9-anhydroTTX & Total & \\
\hline Hepatopancreas & 16.7 & $<0.1$ & $<0.1$ & $<0.1$ & $<0.1$ & $<0.1$ & - \\
\hline Intestine & 64.7 & 10.7 & 1.8 & 0.7 & 1.7 & 14.9 & 4.3 \\
\hline Muscle & 17.9 & 5.9 & $<0.1$ & $<0.1$ & $<0.1$ & 5.9 & 3.0 \\
\hline Skin & 326.1 & 37.4 & $<0.1$ & 10.3 & 0.2 & 47.9 & 6.8 \\
\hline Gonad & 41.0 & $<0.1$ & $<0.1$ & $<0.1$ & $<0.1$ & $<0.1$ & - \\
\hline
\end{tabular}

* ELISA determines the total amount of TTX and its analogs (TTXs) including 6-epiTTX, 4-epiTTX, and 5,6,11-trideoxyTTX, but not 4,9-anhydroTTX. ** The ratio of amount of TTXs determined by ELISA to that determined by HPLC-FLD.

In the case of adult newt, 11 individuals were subjected to analyses of both or either ELISA and/or HPLC-FLD for various tissues, whereas the remaining 17 individuals were only subjected to ELISA for the tail part (Table 3). All individuals were found to contain TTXs as far as ELISA analysis was concerned, although the amount varied depending on individuals and tissues. The tail contained the highest amount of TTXs when determined by ELISA, followed by the skin, whereas the levels in liver, intestine, ovary and testis were marginal. As in the case of pufferfish, the amounts of TTXs determined by ELISA were different from those determined by HPLC-FLD. For example, the former values were lower than those of the latter in the tails from sample No. 1 and 8-10 and from the skin from samples No. 7 and 8. On the other hand, the opposite relationship was observed in tails from samples No. 4 and 7, whereas ELISA and HPLC gave comparable values to tails from sample No. 2. 
Table 3. Amount of TTX and its analogs in adult newt Cynops pyrrhogaster (nmol/g).

\begin{tabular}{|c|c|c|c|c|c|c|c|c|c|c|c|c|c|c|c|c|c|c|c|c|c|c|c|c|c|c|c|c|c|c|}
\hline \multirow{3}{*}{$\begin{array}{c}\text { Sample } \\
\text { No. }\end{array}$} & \multicolumn{5}{|c|}{$\begin{array}{l}\text { Liver } \\
\end{array}$} & \multicolumn{6}{|c|}{ Intestine } & \multicolumn{5}{|c|}{$\begin{array}{l}\text { Skin } \\
\end{array}$} & \multicolumn{5}{|c|}{\begin{tabular}{|l|l|l|l|l} 
Tail & \\
\end{tabular}} & \multicolumn{5}{|c|}{ Ovary } & \multirow{2}{*}{\multicolumn{4}{|c|}{$\begin{array}{c}\text { Testis } \\
\text { HPLC.FLD }\end{array}$}} \\
\hline & \multicolumn{2}{|l|}{ EIISA } & \multicolumn{2}{|c|}{ HPLC-FLD } & \multirow[b]{2}{*}{$\begin{array}{c}4,9 \\
\text { anhydroTTX }\end{array}$} & \multirow{2}{*}{$\begin{array}{l}\text { ELSA } \\
\text { TTXs }\end{array}$} & \multirow[b]{2}{*}{ тTX } & \multicolumn{2}{|c|}{ HPLC-FLD } & \multirow[b]{2}{*}{$\begin{array}{c}\text { 4.9- } \\
\text { anhydroTTx }\end{array}$} & \multirow{2}{*}{$\begin{array}{l}\text { EUSA } \\
\text { TTXs }\end{array}$} & \multirow[b]{2}{*}{ TTX } & \multicolumn{2}{|c|}{ HPLC-FLD } & \multirow[b]{2}{*}{$\begin{array}{l}4,9- \\
\text { anhydroTTX }\end{array}$} & \multirow{2}{*}{$\begin{array}{l}\text { ELSA } \\
\text { TTXS }\end{array}$} & \multirow[b]{2}{*}{ TтX } & \multicolumn{2}{|c|}{ HPLC-FLD } & \multirow[b]{2}{*}{$\begin{array}{c}4,9- \\
\text { anhydroTTX }\end{array}$} & \multirow{2}{*}{$\begin{array}{l}\text { ELISA } \\
\text { TTXS }\end{array}$} & & \multicolumn{2}{|c|}{ HPLC-FLD } & \multirow[b]{2}{*}{$\begin{array}{c}4,9-9 \\
\text { anhydroTTX }\end{array}$} & \multirow{2}{*}{$\begin{array}{l}\text { ELISA } \\
\text { TTXS }\end{array}$} & & & & \\
\hline & TTXs & тTх & epiTTX & $\underset{\text { eppiTTx }}{4-}$ & & & & epiTTX & eptTTX & & & & epiTTx & epiTx & & & & epiTTX & epiTTX & & & ттх & $\begin{array}{c}\text { ep-TX } \\
\end{array}$ & epiTTx & & & ттх & eppiTx & $\underset{e p i T T x}{4-4}$ & $\begin{array}{l}4,9.9 \\
\text { anhydroTTx }\end{array}$ \\
\hline $\begin{array}{l}1 \\
2 \\
3 \\
4 \\
5 \\
6 \\
7 \\
8 \\
10 \\
11 \\
12 \\
13 \\
14 \\
15 \\
17 \\
18 \\
10 \\
21 \\
223 \\
24 \\
25 \\
27 \\
28 \\
\end{array}$ & $\begin{array}{c}0.4 \\
2.4 \\
2.9 \\
1.0 \\
1.5 \\
12.0 \\
1.8 \\
\vdots \\
\vdots \\
\vdots \\
\vdots \\
\vdots \\
\vdots \\
\vdots \\
\vdots \\
\vdots \\
\vdots \\
\end{array}$ & $\begin{array}{l}\vdots \\
\vdots \\
\vdots \\
0.1 \\
0.1 \\
0.1 \\
0.1 \\
0.1 \\
\vdots \\
\vdots \\
\vdots \\
\vdots \\
\vdots \\
\vdots \\
\vdots \\
\end{array}$ & $\begin{array}{c}\vdots \\
\vdots \\
\vdots \\
<0.1 \\
50.9 \\
<0.1 \\
<0.1 \\
<0.1 \\
\vdots \\
\vdots \\
\vdots \\
\vdots \\
\vdots \\
\vdots \\
\vdots\end{array}$ & $\begin{array}{c}\vdots \\
\vdots \\
\vdots \\
0.1 \\
<0.1 \\
10.4 \\
10.1 \\
0.1 \\
\vdots \\
\vdots \\
\vdots \\
\vdots \\
\vdots \\
\vdots \\
\vdots \\
\vdots \\
\end{array}$ & $\begin{array}{c}\vdots \\
\vdots \\
\vdots \\
0.1 \\
00.1 \\
00.1 \\
00.1 \\
00.1 \\
\vdots \\
\vdots \\
\vdots \\
\vdots \\
\vdots \\
\vdots \\
\vdots\end{array}$ & $\begin{array}{c}2.5 \\
147 \\
8.2 \\
148 \\
157 \\
40.0 \\
\vdots \\
\vdots \\
\vdots \\
\vdots \\
\vdots \\
\vdots \\
\vdots \\
\vdots \\
\vdots \\
\vdots \\
\vdots \\
\end{array}$ & $\begin{array}{c}\vdots \\
\vdots \\
\vdots \\
0.1 \\
0.1 \\
0.1 \\
2.2 \\
\vdots \\
\vdots \\
\vdots \\
\vdots \\
\vdots \\
\vdots \\
\end{array}$ & $\begin{array}{c}\vdots \\
\vdots \\
\vdots \\
<0.1 \\
2.9 \\
20.1 \\
8.8 \\
\vdots \\
\vdots \\
\vdots \\
\vdots \\
\vdots \\
\vdots \\
\vdots \\
\vdots\end{array}$ & $\begin{array}{c}\vdots \\
\vdots \\
\vdots \\
<0.1 \\
20.6 \\
<0.1 \\
<0.1 \\
\vdots \\
\vdots \\
\vdots \\
\vdots \\
\vdots \\
\vdots \\
\vdots \\
\end{array}$ & $\begin{array}{c}\vdots \\
\vdots \\
\vdots \\
<0.1 \\
<0.1 \\
<0.1 \\
<0.1\end{array}$ & 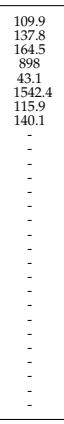 & $\begin{array}{c} \\
\vdots \\
\vdots \\
20.1 \\
22.2 \\
250.6 \\
55.1 \\
246.2 \\
\vdots \\
\vdots \\
\vdots \\
\vdots \\
\vdots \\
\vdots \\
\vdots \\
\vdots \\
\end{array}$ & 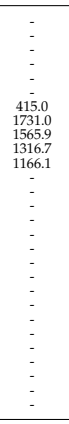 & 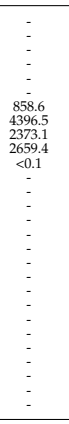 & $\begin{array}{l}19.0 \\
10.01 \\
950.1 \\
20.1 \\
25.7\end{array}$ & 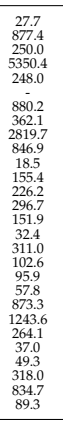 & $\begin{array}{c}250.6 \\
43.1 \\
88.6 \\
13.2 \\
13.0 \\
83.7 \\
13.6 \\
1275.6 \\
140.4 \\
360.3 \\
\vdots \\
\vdots \\
\vdots \\
\vdots \\
\vdots \\
\vdots \\
\vdots \\
\vdots\end{array}$ & 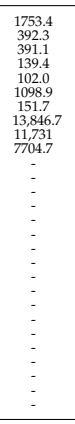 & 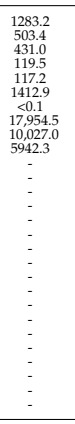 & 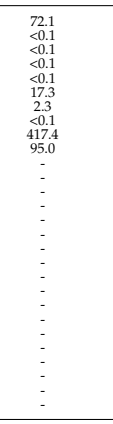 & $\begin{array}{l}\vdots \\
\vdots \\
\vdots \\
\vdots \\
\vdots \\
\vdots\end{array}$ & $\begin{array}{c} \\
\vdots \\
\vdots \\
<0.1 \\
<2.1 \\
27.3\end{array}$ & $\begin{array}{c}\vdots \\
\vdots \\
\vdots \\
9.9 \\
40.1 \\
<0.1\end{array}$ & $\begin{array}{c} \\
\vdots \\
\vdots \\
<0.1 \\
<0.1 \\
<0.1\end{array}$ & $\begin{array}{c}\vdots \\
\vdots \\
\vdots \\
<0.1 \\
<0.1 \\
0.1\end{array}$ & $\begin{array}{l}\vdots \\
\vdots \\
\vdots \\
\vdots\end{array}$ & $\begin{array}{c}<0.1 \\
0.7 \\
\vdots \\
\vdots \\
\vdots \\
\vdots \\
\vdots \\
\vdots \\
\vdots \\
\vdots\end{array}$ & $\begin{array}{c}30.8 \\
5.7 \\
\vdots \\
\vdots \\
\vdots \\
\vdots \\
\vdots \\
\vdots\end{array}$ & $\begin{array}{c}<0.1 \\
<0.1 \\
\vdots \\
\vdots \\
\vdots \\
\vdots \\
\vdots \\
\vdots \\
\vdots\end{array}$ & $\begin{array}{c}0.1 \\
<0.1 \\
\vdots \\
\vdots \\
\vdots \\
\vdots \\
\vdots \\
\vdots \\
\vdots\end{array}$ \\
\hline 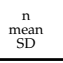 & $\begin{array}{c}7.0 \\
6.0 \\
5.4 \\
\end{array}$ & $\begin{array}{c}5 \\
0.1 \\
<0.1 \\
<0.1 \\
\end{array}$ & $\begin{array}{c}5 \\
10.2 \\
22.7 \\
\end{array}$ & $\begin{array}{r}5.3 \\
3.3 \\
7.3\end{array}$ & $\begin{array}{c}5 \\
50.1 \\
0.1 \\
0.1\end{array}$ & $\begin{array}{r}7 \\
12.5 \\
13.2 \\
\end{array}$ & $\begin{array}{l}4.6 \\
0.6 \\
1.1 \\
\end{array}$ & $\begin{array}{r}4.9 \\
2.9 \\
4.1 \\
\end{array}$ & $\begin{array}{c}4 \\
7.4 \\
1.4 .8 \\
\end{array}$ & $\begin{array}{c}4 \\
<0.1 \\
<0.1 \\
<0.1 \\
\end{array}$ & $\begin{array}{c}8 \\
6230 \\
5399.4 \\
\end{array}$ & $\begin{array}{r}5 \\
132.8 \\
111.1 \\
\end{array}$ & $\begin{array}{c}125 \\
\begin{array}{c}5 \\
5099.9\end{array} \\
\end{array}$ & $\begin{array}{c}205 \\
255.5 \\
1703.2 \\
\end{array}$ & $\begin{array}{l}75 \\
73.7 \\
108.5 \\
\end{array}$ & $\begin{array}{c}27 \\
622.0 \\
111.4 \\
\end{array}$ & $\begin{array}{r}10 \\
355.2 \\
533.8 \\
\end{array}$ & $\begin{array}{c}10 \\
3731.1 \\
5313.9 \\
\end{array}$ & $\begin{array}{c}100 \\
3779.1 \\
5958.3 \\
\end{array}$ & $\begin{array}{c}10.0 \\
60.4 \\
130.1 \\
3\end{array}$ & $\begin{array}{r}32.0 \\
31.0 \\
40.5\end{array}$ & $\begin{array}{c}3.1 \\
9.1 \\
15.8 \\
\end{array}$ & $\begin{array}{r}3 \\
16.7 \\
20.9 \\
\end{array}$ & $\begin{array}{c}3 \\
<0.1 \\
<0.1 \\
<0.1 \\
\end{array}$ & $\begin{array}{c}3 \\
<0.1 \\
<0.1 \\
<0.1 \\
\end{array}$ & $\begin{array}{l}5.5 \\
7.1 \\
4.0 \\
\end{array}$ & $\begin{array}{c}2 \\
0.3 \\
0.5 \\
\end{array}$ & $\begin{array}{r}12 \\
18.3 \\
17.8 \\
\end{array}$ & $\begin{array}{c}2 \\
<0.1 \\
0.1 \\
0.1\end{array}$ & $\begin{array}{c}2 \\
<0.1 \\
<0.1 \\
\end{array}$ \\
\hline
\end{tabular}


Whole bodies were subjected to ELISA and HPLC-FLD for newt juveniles, eggs and hatched larva. As shown in Tables 4 and 5, only marginal amounts of TTXs were detected by ELISA, but none by HPLC-FLD.

Table 4. Amount of TTX and its analogs in juvenile newt Cynops pyrrhogaster (nmol/g).

\begin{tabular}{ccccc}
\hline \multirow{2}{*}{ Sample No. } & \multicolumn{2}{c}{ Viscera } & \multicolumn{3}{c}{ Tail } \\
\cline { 2 - 5 } & ELISA $^{*}$ & HPLC-FLD & ELISA & HPLC-FLD \\
\hline 1 & 3.0 & $<0.1$ & 8.0 & $<0.1$ \\
2 & 0.6 & $<0.1$ & 0.5 & $<0.1$ \\
3 & 0.7 & $<0.1$ & 4.6 & $<0.1$ \\
4 & 0.5 & -0.1 & 0.8 & $<0.1$ \\
5 & $-* *$ & - & 5.7 & - \\
6 & - & - & 4.7 & - \\
7 & - & - & 1.7 & - \\
8 & - & - & 0.1 & - \\
9 & - & 5 & 1.1 & 4 \\
n & 4 & $<0.1$ & 9 & $<0.1$ \\
mean & 1.2 & $<0.1$ & 2.0 & $<0.1$ \\
\hline SD & 1.2 & -8 & \\
\hline
\end{tabular}

* ELISA determines the total amount of TTX and its analogs (TTXs), including 6-epiTTX, 4-epiTTX, and 5,6,11trideoxyTTX, but not 4,9-anhydroTTX. ** not determined.

Table 5. Amount of TTX and its analogs in eggs and hatched larva of newt Cynops pyrrhogaster $(\mathrm{nmol} / \mathrm{g})$.

\begin{tabular}{ccc}
\hline Sample & ELISA $^{*}$ & HPLC-FLD \\
\hline Egg jelly layer & 0.7 & $<0.1$ \\
Egg yolk & 11.4 & $<0.1$ \\
Larva & 1.8 & $<0.1$
\end{tabular}

* ELISA determines the total amount of TTX and its analogs (TTXs) including 6-epiTTX, 4-epiTTX, and 5,6,11trideoxyTTX, but not 4,9-anhydroTTX.

3.2. Accumulation of TTXs and PSTs in the Newt Exogenously Dosed with Toxic Pufferfish Hepatopancreas, Authentic TDT or dcSTX

The tails were excised from six adult newt specimens collected in 2019 (No. 12, 14, 15, 18, 19 and 21 in Table 3) and subjected to ELISA analysis of TTXs, as described in Section 3.1. After this treatment, all specimens were reared in plastic cases individually for 6 months, while being fed food specifically designed for newts, and their newly developed tails were subjected to the analysis of TTXs again. Because the regenerated tails were so small, only samples No. 18, 19 and 21 were subjected to the analysis of TTXs, whereas the tails of samples No. 12, 14 and 15 were used for the localization of TTXs by the immunohistochemical procedure, as described in the following section. We determined that only three specimens and considerable amounts of TTXs were detected by ELISA, as shown in Table 6. 
Table 6. Amount of TTX and its analogs in initial and regenerated tails of adult newt Cynops pyrrhogaster determined by ELISA *.

\begin{tabular}{ccc}
\hline & Initial Tail & Regenerated Tail \\
\hline 12 & 155.4 & $-* *$ \\
14 & 296.7 & - \\
15 & 151.9 & 37.8 \\
18 & 102.6 & 57.4 \\
19 & 95.9 & 145.7 \\
21 & 873.3 & 3 \\
$\mathrm{n}$ & 6 & 80.3 \\
mean & 279.3 & 57.5
\end{tabular}

* ELISA determines total amount of TTX and its analogs (TTXs) including 6-epiTTX, 4-epiTTX, and 5,6,11trideoxyTTX, but not 4,9-anhydroTTX. ** not determined because regenerated tails (sample Nos. 12, 14 and 15) were subjected to immunohistochemical observation.

Five juveniles collected on 3 October 2018, with a supposed age of 5 months, were reared for one month with a non-toxic diet, and then dosed with the globefish puffer hepatopancreas with the toxicity shown in Table 1 (ca. $50 \mathrm{mg}$ once a week for each individual) for 10 weeks. A part of the tail was dissected prior to the start of the feeding experiments. As shown in Table 7, almost no TTXs were detected in the tail. After the feeding experiment, however, large quantities of TTXs were detected by both ELISA and HPLC-FLD, with the largest being observed in the tail followed by the intestine, liver, skin and ovary. It was noted that the amount of TTX was higher than that of 4,9-anhydroTTX, in agreement with the toxic composition in the original globefish puffer hepatopancreas used for the feeding diet (Tables 1 and 7). However, the quantity of TTXs in the juvenile newt determined by HPLC-FLD was 7.7-9.1-fold higher than that determined by ELISA (Table 7), whereas the former quantity in the globefish puffer hepatopancreas was about 100-fold higher than that of the latter (Table 1).

Table 7. Amount of TTX and its analogs in larvae of newt Cynops pyrrhogaster before and those after dosage with toxic globefish puffer Takifugu flavipterus hepatopancreas as determined by ELISA and by HPLC-FLD (nmol/g).

\begin{tabular}{|c|c|c|c|c|c|c|c|c|c|c|c|}
\hline \multirow{3}{*}{$\begin{array}{c}\text { Sample } \\
\text { No. }\end{array}$} & \multirow{3}{*}{ Tissue } & \multicolumn{6}{|c|}{ Before Dosage } & \multirow{2}{*}{\multicolumn{4}{|c|}{$\begin{array}{c}\text { After Dosage } \\
\text { HPLC-FLD }\end{array}$}} \\
\hline & & \multirow{2}{*}{$\begin{array}{c}\text { ELISA * } \\
\text { TTXs }\end{array}$} & \multicolumn{4}{|c|}{ HPLC-FLD } & \multirow{2}{*}{$\begin{array}{c}\text { ELISA } \\
\text { TTXs }\end{array}$} & & & & \\
\hline & & & TTX & 6-еріТТХ & 4-еріТТХ & $\begin{array}{c}4,9- \\
\text { anhydroTTX }\end{array}$ & & TTX & 6-ерiТTX & 4-еріТTX & $\begin{array}{c}4,9- \\
\text { anhydroTTX }\end{array}$ \\
\hline 1 & Tail & 3.6 & $<0.1$ & $<0.1$ & $<0.1$ & $<0.1$ & $14,382.1$ & $85,014.4$ & $<0.1$ & $<0.1$ & $26,987.2$ \\
\hline \multirow{5}{*}{2} & Tail & 1.9 & $<0.1$ & $<0.1$ & $<0.1$ & $<0.1$ & 6550.4 & $53,328.8$ & $<0.1$ & $<0.1$ & 6060.0 \\
\hline & Liver & - & - & - & - & - & 484.8 & - & - & - & - \\
\hline & Intestine & - & - & - & - & - & 557.5 & - & - & - & - \\
\hline & Skin & - & - & - & - & - & 362.0 & - & - & - & - \\
\hline & Ovary & - & - & - & - & - & 212.5 & - & - & - & - \\
\hline 3 & Tail & 2.2 & $<0.1$ & $<0.1$ & $<0.1$ & $<0.1$ & 2.3 & $<0.1$ & $<0.1$ & $<0.1$ & $<0.1$ \\
\hline 4 & Tail & 2.0 & $<0.1$ & $<0.1$ & $<0.1$ & $<0.1$ & 4.1 & $<0.1$ & $<0.1$ & $<0.1$ & $<0.1$ \\
\hline 5 & Tail & 3.0 & $<0.1$ & $<0.1$ & $<0.1$ & $<0.1$ & 2.2 & $<0.1$ & $<0.1$ & $<0.1$ & $<0.1$ \\
\hline
\end{tabular}

Sample Nos. 1 and 2 were fed toxic diet, whereas samples 3-5, no-toxic diet. Tissues of sample No. 2 were subjected to immunohisotochemical experiments. * ELISA determines the total amount of TTX and its analogs (TTXs) including 6-epiTTX, 4-epiTTX, and 5,6,11-trideoxyTTX, but not 4,9-anhydroTTX.

One live specimen of juvenile newt with a supposed age of about 6 month was dosed with a total of $1475 \mathrm{nmol}$ TDT (as determined by ELISA) mixed in the special newt diet mentioned above. The tail was found to contain $1254 \mathrm{nmol} / \mathrm{g}$ TTXs by ELISA, whereas HPLC-FLD showed no 6-epiTTX, 4-epiTTX and TTX. LC-MS identified TDT with a molecular mass of 272, suggesting that the TDT dosed was not metabolized to TTX or other TTX analogs (data not shown).

Then, a total of $620 \mathrm{nmol}$ of dcSTX prepared previously from the Yezo giant scallop was dosed exogenously to two adult newt specimens collected in 2019, and their tails were 
subjected to PSTs analysis by HPLC-FLD. The newt contained very little or no dcSTX in the tail before dosage, whereas most dcSTX dosed with the diet was detected in the tail after dosage (Table 8). A small amount of dcSTX was also found in the intestine, spermatic duct and skin.

Table 8. Amount of decarbamoylsaxitoxin accumulated in tails of adult newt Cynops pyrrhogaster determined by HPLC-FLD (nmol/g).

\begin{tabular}{ccc}
\hline & \multicolumn{2}{c}{ Sample No. } \\
\cline { 2 - 3 } Tissue & $\mathbf{1}$ & $\mathbf{2}$ \\
\hline Total length $(\mathrm{mm})$ & 101 & 116 \\
Body weight $(\mathrm{g})$ & 5.8 & 7.6 \\
\hline Tail before dosage & 1.8 & $<0.1$ \\
Tail after dosage & 427.4 & 489.9 \\
Liver & 1.5 & 8.9 \\
Stomach & 6.6 & 9.2 \\
Anterior intestine & 11.8 & $<0.1$ \\
Middle intestine & 15.2 & $<0.1$ \\
Posterior intesine & 5.8 & 20.2 \\
Spleen & 8.1 & $<0.1$ \\
Testis & & 3.5 \\
Ovary & 1.5 & 89.1 \\
Spermatic duct & $-*$ & - \\
Oviduct & 7.0 & 39.2 \\
Skin & 35.3 & - \\
Blood & 3.5 & 9.9 \\
Fat body & - &
\end{tabular}

\subsection{Immunohistochemistry for Anatomical Localization of TTXs in Pufferfish and Newt \\ 3.3.1. Pufferfish}

The immunoreaction for TTXs in each tissue of globefish puffer is shown in Figure 1. TTXs-immunoreactive (ir) staining was observed in the hepatopancreas (Figure 1A). The staining in the hepatic region disappeared when the antibody was pre-absorbed overnight at $4{ }^{\circ} \mathrm{C}$ with an excess amount of TTXs, whereas that in the pancreas region seemed to remain (Figure 1B). TTXs-ir staining was also observed in the ovary (Figure 1C); the staining of the oocytes at the perinucleolus stage was intense, whereas maturing eggs were stained lightly. Furthermore, TTXs-ir staining was detected in the sac-like tissues just outside the serous membrane of the intestine (Figure $1 \mathrm{E}, \mathrm{G}$ ) and the gland-like structure of the skin (Figure 1I). These stainings in the ovary, the intestine, and the gland-like structure of the skin were removed by the pre-absorption antibody (Figure 1D,F,H,J). TTXs-ir staining was not detected in the muscle (data not shown).

TTXs-ir staining was observed in the brown-lined puffer in the gland-like structure of the skin (Figure 2A,C), and the staining disappeared when the antibody had been preabsorbed overnight at $4{ }^{\circ} \mathrm{C}$ with an excess amount of TTX (Figure 2B,D). TTXs-ir staining was not detected in the hepatopancreas, intestine, muscle or testis (data not shown). 

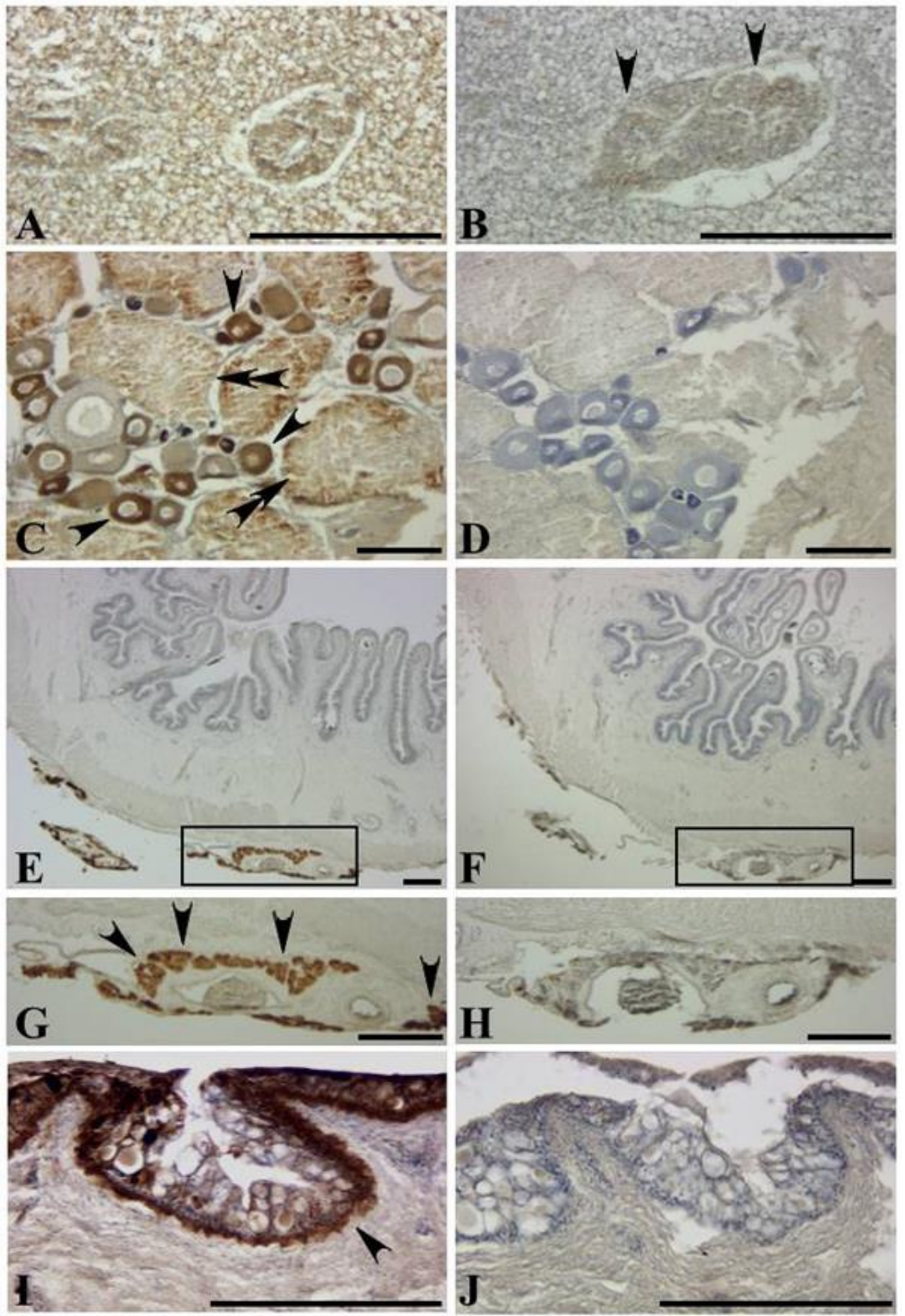

Figure 1. Immunoreaction for tetrodotoxins (TTXs) in various tissues of globefish puffer Takifugu flavipterus before spawning. (A) TTXs-immunoreactive (ir) staining in the hepatopancreas. (B) Adjacent section of panel A, incubated with pre-absorption antibody. No staining was detected in the hepatic region, whereas a faint staining remained in the pancreas region (arrowheads). (C) TTXs-ir staining in the ovary. The staining of the oocytes at the perinucleolus stage (arrowheads) was intense, whereas maturing eggs (double arrowheads) were stained lightly. (D) Adjacent section of "C", which was incubated with pre-absorption antibody. (E) TTXs-ir staining in the intestine. (F) Adjacent section of panel E, which was incubated with pre-absorption antibody. (G) Higher magnification of the boxed area in panel E. TTXs-ir staining in the sac-like tissues just outside the serous membrane of the intestine (arrowheads). (H) Adjacent section of panel G, which was incubated with pre-absorption antibody. (I) TTXs-ir staining in the gland-like structure of the skin (arrowhead). (J) Adjacent section of panel I, which was incubated with pre-absorption antibody. Scale bars indicate $200 \mu \mathrm{m}$. 


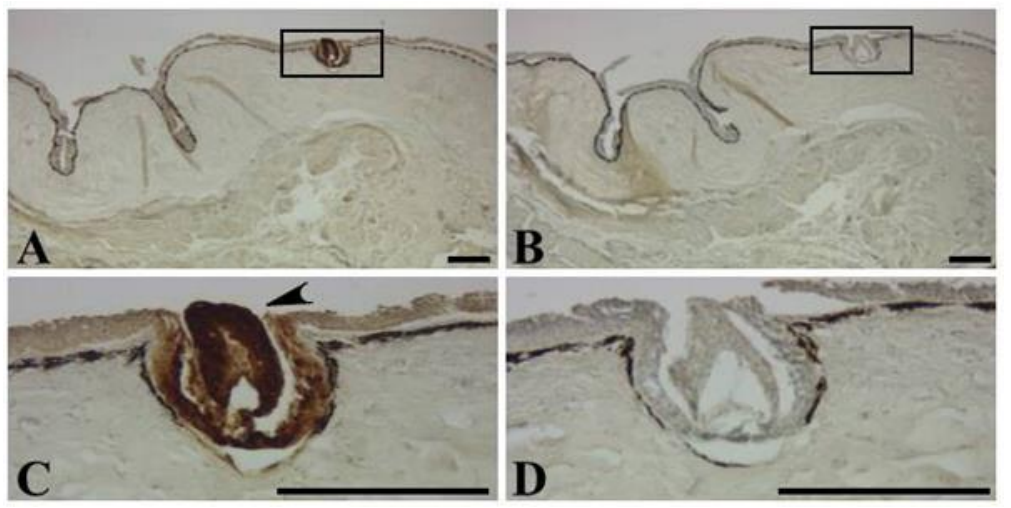

Figure 2. Immunoreaction for TTXs in various tissues of brown-lined puffer Canthigaster revulata. (A) TTXs-ir staining in the skin. (B) Adjacent section of panel A, which was incubated with preabsorption antibody. (C) Higher magnification of the boxed area in panel A. TTXs-ir staining in the gland-like structure of the skin (arrowhead). (D) Adjacent section of panel C, which was incubated with pre-absorption antibody. Scale bars indicate $200 \mu \mathrm{m}$.

\subsubsection{Newts}

TTXs-ir staining was detected in the mature glands in the dermis of the adult tail (Figure 3A). No immunoreactive staining was observed when the antibody had been preabsorbed overnight at $4{ }^{\circ} \mathrm{C}$ with an excess amount of TTXs (Figure 3B). TTXs-ir staining was not detected in the liver, intestine, testis, skin or ovary (data not shown).

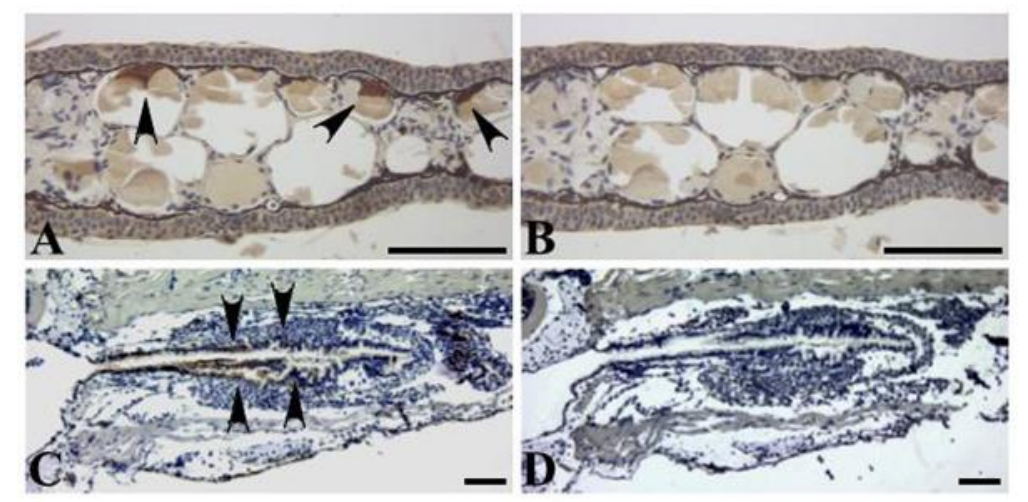

Figure 3. Immunoreaction for TTXs in various tissues of the newt Cynops pyrrhogaster. (A) TTXs-ir staining in the mature glands in dermis of the tail of adult newt (arrowheads). (B) Adjacent section of panel A, which was incubated with pre-absorption antibody. (C) TTXs-ir staining along the esophagus and the stomach of larval newt (arrowheads). (D) Adjacent section of panel C, which was incubated with pre-absorption antibody. Scale bars indicate $200 \mu \mathrm{m}$.

TTXs-ir staining was not detected in the juvenile tail (data not shown). TTXs-ir staining was detected only along the esophagus and the stomach in larva (Figure $3 \mathrm{C}$ ) and the staining was removed by the pre-absorption antibody (Figure 3D).

TTXs-ir staining was detected in the mature glands in the dermis of the regenerated tail (Figure 4A), as observed in the control newt fed a non-toxic diet only (Figure 3A). The staining in the regenerated tail was not detected with the pre-absorption antibody (Figure 4B). 

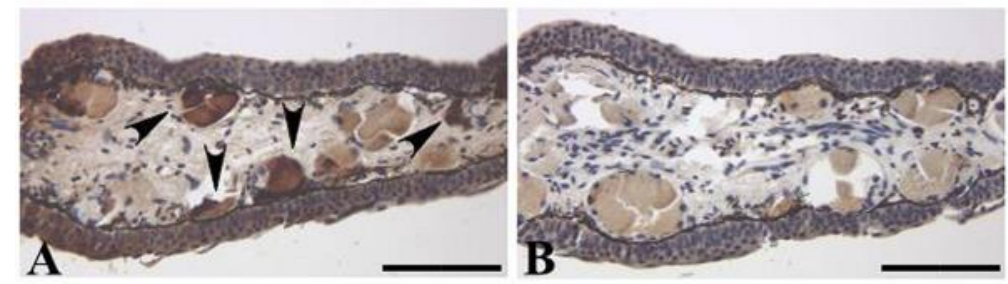

Figure 4. Immunoreaction for TTXs in the regenerated tail of the newt Cynops pyrrhogaster. (A) TTXs-ir staining in the mature glands in dermis of the regenerated tail (arrowheads). (B) Adjacent section of panel A, which was incubated with pre-absorption antibody. Scale bars indicate $200 \mu \mathrm{m}$.

When a larval newt was fed a diet containing the globefish puffer hepatopancreas (Table 7), TTXs-ir staining was detected in the epithelial cells of the intestine (Figure 5A), the ovary (Figure 5C) and the skin (Figure 5E) of the TTXs-administered newt. In the tail, TTXs-ir staining was detected not only in the mucous cells, but also in the dermis (Figure 5G). These stainings in the epithelial cells of the intestine, the ovary, the skin and the tail disappeared when the pre-absorption antibody was used (Figure 5B,D,F,H). In the liver, intense staining was observed with both the normal antibody and the pre-absorption antibody (data not shown).

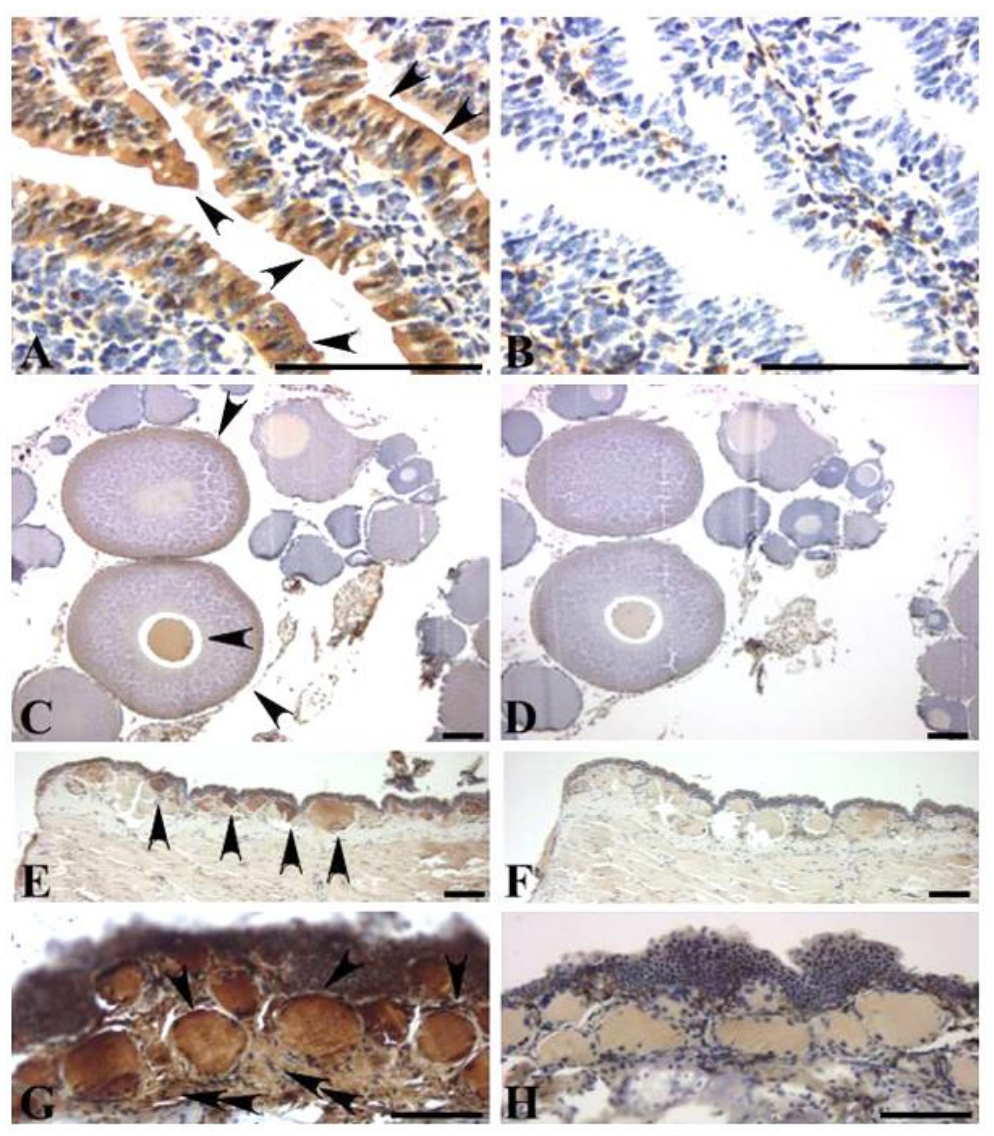

Figure 5. Immunoreaction for TTXs in various tissues of the TTXs-administered newts Cynops pyrrhogaster. (A) TTXs-ir staining in the epithelial cells of the intestine (arrowheads). (B) Adjacent section of panel A, which was incubated with pre-absorption antibody. (C) TTXs-ir staining in the ovary (arrowheads). (D) Adjacent section of panel C, which was incubated with pre-absorption antibody. (E) TTXs-ir staining in the skin (arrowheads). (F) Adjacent section of panel E, which was incubated with pre-absorption antibody. (G) TTXs-ir staining in the mucous cells (arrowheads) and in the dermis (double arrowheads) of the tail. (H) Adjacent section of panel G, which was incubated with pre-absorption antibody. Scale bars indicate $200 \mu \mathrm{m}$. 


\section{Discussion}

The present study was undertaken to analyze TTXs in various tissues of toxin-bearing pufferfish and newt using a specific polyclonal antibody against TTXs and to compare the obtained results with those derived mainly by HPLC-FLD. TDT was measured by LC-MS, because TDT cannot be detected by HPLC-FLD. The anatomical localization of TTXs in these animals was also demonstrated immunohistochemically using the above-mentioned antibody. Furthermore, TTXs and dcSTX were traced for their possible metabolic changes in various tissues when the newts were administered orally with authentic toxins or toxic viscera.

Both sodium channel-blocking natural neurotoxin groups, TTXs and PSTs, consist of several TTX-and STX-analogs, and their metabolic pathways have remained largely unknown. Previously, TDT was identified, and presumed to be a starting material to be converted finally into TTX in pufferfish [25]. Sato and his colleagues have also recently claimed the same possibility using a polyclonal antibody raised against TTX and toxic and non-toxic Lagocephalus pufferfish $[15,16]$. The antibody easily detected TTXs in non-toxic Lagocephalus pufferfish that contained almost exclusively TDT without using LC-MS, which requires complicated procedures, while other fish belonging to this genus contained large amounts of both TTX and TDT [16].

In the present study, we attempted at first to determine the tissue distribution of TTXs in pufferfish and newt using the immunoassay with the specific antibody and LC-FLD, but not using LC-MS. As a result, the ratios of the amount of TTXs in pufferfish determined by ELISA to that determined by HPLC-FLD were changed depending on individuals. These results suggest that pufferfish contained TTX analogs other than 6-epiTTX, 4-epiTTX and 1,9anhydroTTX - presumably TDT. There are several TTX analogs reported so far, in addition to the above-mentioned analogs, such as 4,9-anhydroTTX, 5-deoxyTTX, 11-deoxyTTX and 11-oxoTTX [35]. Alternatively, HPLC-FLD would have detected contaminants with the same elution times as those of TTXs. In the case of the adult newt, several individuals showed an amount of TTXs determined by ELISA lower than that determined by HPLCFLD. Thus, our hypothesis that ELISA would detect the presence of a large amount of TDT in toxin-bearing animals was not necessarily verified. In contrast to the adult newt, juvenile, hatched larva and eggs contained very low amounts of TTXs (Tables 4 and 5), suggesting that the newt accumulates exogenous TTXs or synthesizes them endogenously, although the mechanisms involved are uncertain. Considerable individual variations in toxin levels have been reported within and among populations of red-spotted newt, Notophthalmus viridescens, inhabiting North America, where the exogenous source of TTX derived either via the food chain or via the synthesis of symbiotic bacteria has been suggested to explain such high variability and the lack of TTX in certain populations [36]. The TTX-producing bacterial strains, isolated as bacterial symbionts from toxic newts, consisted of four genera, including Aeromonas, Pseudomonas, Shewanella, and Sphingopyxis, from rough-skinned newts, Taricha granulosa [37].

In spite of such uncertainty, we attempted experiments to determine the metabolism of endogenous and exogenous toxins, using newt specimens the tails of which were cut and then regenerated naturally. After 6 months rearing, the regenerated tails, though they were much shorter than their original counterparts, accumulated about half the amount of TTXs originally observed before the removal of the tail, as determined by ELISA (Table 6). These results suggest that not only symbionts, but also biosynthesis, in the newt are responsible for the production of TTXs.

We supplied a non-toxic diet during rearing, and the TTXs found in the regenerated tail are likely to have been transferred from somewhere in the body, or biosynthesized internally. Therefore, feeding experiments were performed with larval newts using the globefish puffer hepatopancreas, resulting in the accumulation of TTX and 4,9-anhydroTTX predominantly in the tail (Table 7). Further experiments using adult newts for four weeks with authentic TDT in diets demonstrated that TDT was recovered at a yield of $85 \%$ in the tail, but no TTX or its analogs were detected. These results suggest that TDT could 
not be metabolized to TTX or its other analogs under the present experimental conditions. Additional experiments were further performed using dcSTX, another highly neurotoxic component comparable to TTXs. When dcSTX was introduced as a diet in newt-specific food, almost all the dcSTX was recovered, and the accumulation was the highest in the tail, followed by the spermatic duct, skin and intestine (Table 8).

Previously, Kodama et al. discovered TTX-secreting glands in pufferfish which have gland-like structures in the skin [23]. These cells are completely enclosed by epithelial cells with developed microfilmaments, except at their opening to the lumen. Tanu et al. immunohistochemically localized TTX in the skin of a brackishwater puffer Tetraodon steindachneri using monoclonal antibody against TTX, although they observed TTX localization only on the periphery of the TTX-secreting glands [18]. In the present study, secretory glands were apparent in both globefish and brown-lined puffers, and showed a positive reaction with the polyclonal antibody together with the epidermis layers (Figures 1 and 2). The antibody reaction was also observed in the hepatic region, ovary and sac-like tissues just outside the serous membrane of the intestine (Figure 1). Pufferfish are known to have a hepatopancreas in place of the liver, where the pancreas is surrounded by and bound to the hepatic cells [38]. Interestingly, the immunoreaction was observed with hepatic cells, but almost nothing was observed in the pancreas (Figure 1A).

The adult newt tail and the regenerated tail showed positive reactions in the mature glands in their dermis, as reported by Tsuruda et al. [21]; the newt secreted an appreciable amount of TTX and 6-epiTTX from the skin following handling stimulus, suggesting that the newt releases TTX via the mature glands in its dermis. Interestingly, the newt dosed with toxic tissues displayed staining not only in the intestine, the ovary, and the skin, but also in the tail (Figure 5G). Thus, it is indicated that TTX transfers from the body to the tail.

In conclusion, the present study analyzed TTXs in various tissues of toxin-bearing pufferfish and newt using the specific polyclonal antibody against TTXs, and compared the obtained results with those obtained by HPLC-FLD and LC-MS. The anatomical localization of TTXs in these animals was also demonstrated by an immunohistochemical procedure using the polyclonal antibody. Furthermore, TTXs as well as dcSTX were traced for their dynamic changes in tissue distribution when these animals were fed toxic animal tissues exogenously to provide toxins. Here, the newt was the predominant target, and pufferfish, which are well-studied in terms of toxin distribution, were used as the reference, although we only subjected one each of two species of pufferfish to analyses. The obtained results suggest that TTXs absorbed from the environment are transferred to and accumulated in various organs or tissues in a species-specific manner. In spite of our extensive work, however, the synthetic or metabolic pathway(s) of TTXs have remained largely unknown. To cope with such mysterious and tantalizing questions, we need to perform further experiments on the environmental symbionts and/or endogenous factors that may interact with toxin-bearing animals for toxin synthesis and metabolism.

Author Contributions: Conceptualization, S.S., S.W.; Methodology, S.S., M.A.; Software, S.S., M.A.; validation, S.S., M.A, K.Y. (Kaito Togashi) and K.T. (Kentaro Takada); formal analysis, M.A., N.M.; investigation, R.K., K.T. (Kaito Togashi); resources, S.S., S.W.; data curation, S.S., M.A.; writing—original draft preparation, S.S., M.A.; writing—review and editing, S.W.; visualization, M.A.; supervision, S.W.; project administration, S.S.; funding acquisition, None. All authors have read and agreed to the published version of the manuscript.

Funding: This research received no external funding.

Institutional Review Board Statement: Animal treatment in this study was conducted in compliance with the codes of ethics at Kitasato University, MB1800510 and MB190510.

Informed Consent Statement: Not applicable.

Data Availability Statement: The data that support the findings of this study are available from the corresponding author, [S.S.], upon reasonable request. 
Acknowledgments: We are grateful to Mitsuru Sato, Wonder Labo, Numazu, Shizuoka Prefecture, Japan, for kindly collecting the newts. We also thank Fuka Sakayauchi, School of Marine Biosciences, Kitasato University, for her help in this study.

Conflicts of Interest: The authors declare no conflict of interest.

\section{References}

1. Narahashi, T.; Moore, J.W.; Poston, R.N. Tetrodotoxin derivatives: Chemical structure and blockage of nerve membrane conductance. Science 1967, 156, 976-979. [CrossRef]

2. Kao, C.Y. Actions of nortetrodotoxin on frog muscle and squid axon. Toxicon 1982, 20, 1043-1050. [CrossRef]

3. Takahashi, D.; Inoko, Y. Unter suchungen über das Fugugift. Cent. Meb. Wiss 1889, 27, 529-530.

4. Takahashi, D.; Inoko, Y. Chemische unter suchungen über das Fugugift. Cent. Meb. Wiss 1889, 27, 881-882.

5. Mosher, H.S.; Fuhrman, F.A.; Buchwald, H.D.; Fischer, H.G. Tarichatoxin-tetrodotoxin: A potent neurotoxin. Science 1964, 144, 1100-1110. [CrossRef] [PubMed]

6. Noguchi, T.; Hashimoto, Y. Isolation of tetrodotoxin from a goby Gobius Criniger. Toxicon 1973, 11, 305-307. [CrossRef]

7. Kim, Y.H.; Brown, G.B.; Mosher, H.S.; Fuhrman, F.A. Tetrodotoxin: Occurrence in atelopid frogs of Costa Rica. Science 1975, 189, 151-152. [CrossRef]

8. Noguchi, T.; Arakawa, O. Tetrodotoxin-Distribution and accumulation in aquatic organisms, and cases of human intoxication. Mar. Drugs 2008, 6, 220-242. [CrossRef]

9. Biessy, L.; Boundy, M.J.; Smith, K.F.; Harwood, D.T.; Hawes, I.; Wood, S.A. Tetrodotoxin in marine bivalves and edible gastropods: A mini-review. Chemosphere 2019, 236, 124404. [CrossRef]

10. Yasumoto, T.; Yasumura, D.; Yotsu, M.; Michishita, T.; Endo, A.; Kotaki, Y. Bacterial production of tetrodotoxin and anhydrotetrodotoxin. Agric. Biol. Chem. 1986, 50, 793-795. [CrossRef]

11. Noguchi, T.; Hwang, D.F.; Arakawa, O.; Sugita, H.; Deguchi, Y.; Shida, Y.; Hashimoto, K. Vibrio alginolyticus, a tetrodotoxinproducing bacterium, in the intestines of the fish Fugu vermicularis vermicularis. Mar. Biol. 1987, 94, 625-630. [CrossRef]

12. Landsberg, J.H.; Hall, S.; Johannessen, J.N.; White, K.D.; Conrad, S.M.; Abbott, J.P.; Flewelling, L.J.; Richardson, R.W.; Dickey, R.W.; Jester, E.L.E.; et al. Saxitoxin puffer fish poisoning in the United States, with the first report of Pyrodinium bahamense as the putative toxin source. Environ. Health Perspect. 2006, 114, 1502-1507. [CrossRef]

13. Kodama, M.; Ogata, T.; Noguchi, T.; Maruyama, J.; Hashimoto, K. Occurrence of saxitoxin and other toxins in the liver of the pufferfish Takifugu Pardalis. Toxicon 1983, 21, 897-900. [CrossRef]

14. Sato, S.; Ogata, T.; Borja, V.; Gonzales, C.; Fukuyo, Y.; Kodama, M. Frequent occurrence of paralytic shellfish poisoning toxins as dominant toxins in marine puffer from tropical water. Toxicon 2000, 38, 1101-1109. [CrossRef]

15. Sato, S.; Takaishi, S.; Yasumoto, K.; Watabe, S. Novel polyclonal antibody raised against tetrodotoxin using its haptenic antigen prepared from 4,9-anhydrotetrodotoxin reacted with 1,2-ethaneditiol and further reacted with keyhole limpet hemocyanin. Toxins 2019, 11, 551. [CrossRef]

16. Thuy, L.V.; Yamamoto, S.; Kawaura, R.; Takemura, N.; Yamaki, K.; Yasumoto, K.; Takada, K.; Watabe, S.; Sato, S. Tissue distribution of tetrodotoxin and its analogs in Lagocephalus pufferfish collected in Vietnam. Fish. Sci. 2020, 86, 1101-1110. [CrossRef]

17. Sato, S.; Takata, Y.; Kondo, S.; Kotoda, A.; Hongo, N.; Kodama, M. Quantitative ELISA kit for paralytic shellfish toxins coupled with sample pretreatment. J. AOAC Int. 2014, 97, 339-344. [CrossRef]

18. Tanu, M.B.; Mahmud, Y.; Takatani, T.; Kawatsu, K.; Hamano, Y.; Arakawa, O.; Noguchi, T. Localization of tetrodotoxin in the skin of a brackishwater puffer Tetraodon steindachneri on the basis of immunohistological study. Toxicon 2002, 40, 103-106. [CrossRef]

19. Itoi, S.; Yoshikawa, S.; Tatsuno, R.; Suzuki, M.; Asahina, K.; Yamamoto, S.; Takanashi, S.; Takatani, T.; Arakawa, O.; Sakakura, Y.; et al. Difference in the localization of tetrodotoxin between the female and male pufferfish Takifugu niphobles, during spawning. Toxicon 2012, 60, 1000-1004. [CrossRef]

20. Itoi, S.; Yoshikawa, S.; Asahina, K.; Suzuki, M.; Ishizuka, K.; Takimoto, N.; Mitsuoka, R.; Yokoyama, N.; Detake, A.; Takayanagi, C.; et al. Larval pufferfish protected by maternal tetrodotoxin. Toxicon 2014, 78, 35-40. [CrossRef]

21. Tsuruda, K.; Arakawa, O.; Kawatsu, K.; Hamano, Y.; Takatani, T.; Noguchi, T. Secretory glands of tetrodotoxin in the skin of the Japanese newt Cynops pyrrhogaster. Toxicon 2002, 40, 131-136. [CrossRef]

22. Mebs, D.; Arakawa, O.; Yotsu-Yamashita, M. Tissue distribution of tetrodotoxin in the red-spotted newt Notophthalmus viridescens. Toxicon 2010, 55, 1353-1357. [CrossRef] [PubMed]

23. Kodama, M.; Sato, S.; Ogata, T.; Suzuki, Y.; Kaneko, T.; Aida, K. Tetrodotoxin secreting glands in the skin of puffer fishes. Toxicon 1986, 24, 819-829. [CrossRef]

24. Yotsu-Yamashita, M.; Yamagishi, Y.; Yasumoto, T. 5,6,11-trideoxytetrodotoxin from the puffer fish, Fugu poecilonotus. Tetrahedron Lett. 1995, 36, 9329-9332. [CrossRef]

25. Jang, J.; Yotsu-Yamashita, M. Distribution of tetrodotoxin, saxitoxin, and their analogs among tissues of the puffer fish Fugu pardalis. Toxicon 2006, 48, 980-987. [CrossRef] [PubMed]

26. Matsumura, K. In vivo neutralization of tetrodotoxin by a monoclonal antibody. Toxicon 1995, 33, 1239-1241. [CrossRef]

27. Matsumura, K. A monoclonal antibody against tetrodotoxin that reacts to the active group for the toxicity. Eur. J. Pharmacol. Environ. Toxicol. Pharmacol. 1995, 293, 41-45. [CrossRef] 
28. Watabe, S.; Sato, Y.; Nakaya, M.; Hashimoto, K.; Enomoto, A.; Kaminogawa, S.; Yamauchi, K. Monoclonal antibody raised against tetrodonic acid, a derivative of tetrodotoxin. Toxicon 1989, 27, 265-268. [CrossRef]

29. Kawatsu, K.; Hamano, Y.; Yoda, T.; Terano, Y.; Shibata, T. Rapid and highly sensitive enzyme immunoassay for quantitative determination of tetrodotoxin. Jpn. J. Med. Sci. Biol. 1997, 50, 133-150. [CrossRef] [PubMed]

30. Sato, S.; Fujita, S.; Mori, M. The Method for Producing Decarbamoylsaxitoxin and Analogs Thereof. JP2016-204270, 8 December 2016. (In Japanese)

31. Sato, S.; Kodama, M. Puffer fish toxin. Guidel. Food Hyg. Insp. Part Phys. Chem. Jpn. Soc. Food Hyg. Tokyo 2015, 813-819.

32. Yotsu, M.; Endo, A.; Yasumoto, T. An improved tetrodotoxin analyzer. Agric. Biol. Chem. 1989, 53, 893-895. [CrossRef]

33. Oshima, Y. Post-column derivatization HPLC methods for paralytic shellfish poisons. In Manual on Harmful Marine Microalgae; Hallegraeff, G.M., Anderson, D.M., Cembella, A.D., Eds.; UNESCO: Paris, France, 1995; pp. 81-94.

34. Amano, M.; Amiya, N.; Yokoyama, T.; Onikubo, K.; Yamamoto, N.; Takahashi, A. Immunohistochemical detection of corticotropinreleasing hormone (CRH) in the brain and pituitary of the hagfish. Eptatretus Burgeri. Gen. Comp. Endocrinol. 2016, 236, 174-180. [CrossRef] [PubMed]

35. Yotsu-Yamashita, M.; Abe, Y.; Kudo, Y.; Ritson-Williams, R.; Paul, V.; Konoki, K.; Cho, Y.; Adachi, M.; Imazu, T.; Nishikawa, T.; et al. First identification of 5,11-dideoxytetrodotoxin in marine animals, and characterization of major fragment ions of tetrodotoxin and its analogs by high resolution ESI-MS/MS. Mar. Drugs 2013, 11, 2799-2813. [CrossRef] [PubMed]

36. Yotsu-Yamashita, M.; Gilhen, J.; Russell, R.W.; Krysko, K.L.; Melaun, C.; Kurz, A.; Kauferstein, S.; Kordis, D.; Mebs, D. Variability of tetrodotoxin and of its analogues in the red-spotted newt, Notophthalmus viridescens (Amphibia: Urodela: Salamandridae). Toxicon 2012, 59, 257-264. [CrossRef]

37. Vaelli, P.M.; Theis, K.R.; Williams, J.E.; O'connell, L.A.; Foster, J.A.; Eisthen, H.L. The skin microbiome facilitates adaptive tetrodotoxin production in poisonous newts. eLife 2020, 9, e53898. [CrossRef]

38. Akiyoshi, H.; Inoue, A.; Hamana, A. Comparative histochemical study of the livers of marine fishes in relation to their behavior. Bull. Fac. Life Env. Sci. Shimane Univ. 2001, 6, 7-16. 